\title{
Horizontal Monitoring in Austria: subjective representations by tax officials and company employees
}

\author{
Janina Enachescu' ${ }^{1}$ Maximilian Zieser ${ }^{1,2}$.

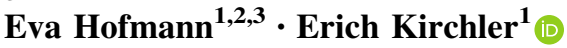

Received: 9 April 2018/Accepted: 19 June 2018/Published online: 6 July 2018

(C) The Author(s) 2018

\begin{abstract}
The implementation of Horizontal Monitoring (HM) in Austria represents a shift in the prevailing command-and-control paradigm towards enhanced cooperation between taxpayers and tax authorities. In the present paper, we assess how $\mathrm{HM}$ is perceived by different stakeholder groups when it was introduced as a pilot project embedded in the "Fair Play Initiative" launched by the Austrian Ministry of Finance. We collected quantitative and qualitative data from tax auditors and staff of tax offices responsible for large-scale enterprises who were either directly involved or not involved in the HM pilot project, from employees of participating enterprises as well as from employees of enterprises which did not participate in the project. Results show that representations of HM were most positive among employees from HM companies and tax officials directly involved, whereas participants from the tax administration who did not take part in the project were skeptical at the beginning and remained skeptical over time. As shown in organizational change studies, the acceptance or resistance regarding the paradigm change represented by HM may originate from uncertainty and misperceptions of its goals and strategies and from speculations, particularly by poorly informed members.
\end{abstract}

Keywords Tax compliance $\cdot$ Horizontal monitoring $\cdot$ Cooperative compliance · Organizational change

Janina Enachescu, Maximilian Zieser, Eva Hofmann and Erich Kirchler contributed equally to the study.

Erich Kirchler

erich.kirchler@univie.ac.at

1 University of Vienna, Vienna, Austria

2 Vienna University of Economics and Business, Vienna, Austria

3 Coventry University, Coventry, England, UK 


\section{Introduction}

Traditionally, the relationship between taxpayers and tax authorities has been strictly hierarchical and was characterized by retrospective audits and the threat of fines as means to enforce compliance. This approach is based on the neo-classical economic model, which assumes that tax compliance and evasion are merely the result of a rational decision process under risk with the goal of maximizing one's own utility (Allingham and Sandmo 1972). In contrast to the rational model, psychological theories hold that social representations of taxation, personal norms and social norms, perceptions of distributive and procedural justice, and trust in the authorities shape taxpayers' behavior (Kirchler 2007; Tyler 1997). Psychological research emphasizes the importance of respectful treatment of taxpayers and service provision which promote voluntary compliance and should be regarded as supplements to enforcement measures (Alm and Torgler 2011). Tax authorities need to balance enforcement measures and respectful treatment in order to maintain the "psychological contract" of cooperation with taxpayers to effectively promote voluntary tax compliance (Feld and Frey 2007).

The command-and-control paradigm has long prevailed among tax authorities fighting tax evasion and it is still the dominant paradigm in practice. However, at least since globally operating corporations engage in increasingly aggressive tax planning and tax avoidance strategies rather than in illegal activities such as evasion, the limitations of the command-and-control paradigm have become evident. In 2008, the OECD Forum on Tax Administration (OECD 2008) developed the concept of "enhanced relationships", later coined "cooperative compliance" (OECD 2013), in order to face the new challenges of globally interlaced taxation systems, such as aggressive tax planning and flight to tax havens. Moreover, research in economic psychology and behavioral economics has contributed to rethinking public administration paradigms and has promoted the development of concepts such as "Good Public Governance". The Austrian approach to "Good Public Governance" explicitly acknowledges the importance of cooperative relations and services (Ehrke-Rabel and Gunacker-Slawitsch 2014; Müller 2014).

In cooperative compliance programs such as Horizontal Monitoring (HM), the strictly "vertical" relationship between taxpayers and tax authorities, which is based on command-and-control, is challenged. Instead, cooperation at eye level and the adherence to fair rules are expected to bear advantages for both taxpayers and authorities. The move from "vertical" to "horizontal monitoring" is expected to promote mutual trust and cooperation by means of commercial awareness, impartiality, proportionality, and responsiveness by the tax authorities on the one hand, and disclosure and transparency by taxpayers on the other hand (Bundesministerium für Finanzen 2012; OECD 2008; Stevens et al. 2012).

In HM, taxation strategies are monitored in an ongoing process and uncertainties are discussed and solved when they arise rather than negotiated in retrospect. While companies adopt internal fiscal control systems and disclose tax information on a regular basis, tax authorities commit to offering timely solutions to tax-related enquiries and to acting transparently (Bundesministerium für Finanzen 2012). HM 
offers advantages for both parties alike: Tax authorities benefit from timely tax collection, adequate tax control frameworks, and full information disclosure by the companies, while for participating companies the continuous, on-time monitoring reduces complexity and fosters planning and legal security.

Legal and planning certainty are advertised as strong benefits of HM for participating companies. Eichfelder and Kegels (2014) provide evidence that customer-friendly tax administration reduces complexity and compliance costs. Theoretical analyses in the field of behavioral economics at the firm-level suggest that greater uncertainty in the interpretation of tax laws encourages firms to develop aggressive tax planning strategies (Alm 2014). Experimental evidence supports this notion by showing that reduced uncertainty can increase correct filing and tax compliance (e.g., Alm et al. 2010). However, findings are equivocal: McGuire et al. (2014) find that high operational uncertainty can be negatively associated with aggressive tax planning.

The concept of HM was developed and first introduced in the Netherlands in 2005 (de Widt and Oats 2017; Stevens et al. 2012; van der Hel-van Dijk and Poolen 2013) for large companies that had proven to be compliant in the past and were willing to participate in the project. In Austria, HM was introduced as a pilot project in July 2011, embedded in the "Fair Play Initiative" launched by the Austrian Ministry of Finance. After the pilot phase, the Austrian Ministry of Finance is now preparing for the long-term implementation of HM.

In the Austrian HM project, only enterprises falling under the responsibility of the large business auditing unit could apply, which generally included all businesses with annual turnovers over ten million Euro. After applying for HM, companies underwent an initial audit to assess their suitability for the project. To be admitted, companies also had to implement a tax control framework and had to demonstrate a reliable tax strategy in the past (Schrittwieser and Woischitzschläger 2014; Stiastny 2015). Following admittance, company representatives signed a declaration of intent together with the Austrian tax authorities. From a legal perspective, the relationship between companies and the tax authorities remained largely unchanged (Bundesministerium für Finanzen 2012; Stiastny 2015). Indeed, HM was mainly based on trust and voluntary cooperation between the two parties: Companies committed to acting transparently and to developing their internal tax risk management, while tax authorities refrained from conducting ex-post audits and provided non-binding advice and interpretations on current taxation issues.

In the regular HM process, companies' accountant managers met quarterly with the responsible tax auditors. During these meetings, comprehensive presentations and documentation of all current taxation issues took place and the tax authorities provided feedback on open questions (Schrittwieser and Woischitzschläger 2014; Stiastny 2015). Participating enterprises ultimately consisted of thirteen company groups with various national and international corporate structures and a wide range of business activities, including energy, technology, building materials, apparel, logistics, food, and drinks.

The implementation of cooperative compliance models in general and of $\mathrm{HM}$ in particular bears various challenges as it represents a major organizational change program. Participating companies must accept cooperating with the tax authorities 
and agree to fully disclose their tax strategies. On the part of tax authorities, HM is accompanied by a paradigm shift from command-and-control to mutual trust and cooperation. The paradigm shift entails the risk of being perceived as a "sweet deal" for companies and as fostering opportunities for corruption (Stiastny 2015). It is thus highly relevant to assess subjective beliefs, opinions, and attitudes as reflected in the subjective representations of HM by participating tax officials and company employees, by tax officials not directly involved, and by employees of non-participating companies. At the beginning of the HM pilot project, the Austrian Ministry of Finance committed to assess subjective representations of HM held by tax officials and company representatives. The goal to understand acceptance and resistance towards the new paradigm is of paramount importance to effectively plan information strategies to avoid misunderstandings and reduce skepticism.

Studies on organizational change stress staff's and clients' resistance to change. Employees may fear losing their status in the organization or missing out on the advantages of change, and they may expect failure or lack trust due to poor information. As a result, they may not be sufficiently committed to supporting the change process. Low commitment and resistance are often observed among those who feel inadequately informed about goals and change strategies. Poor information may originate from a lack of communication as well as from rumors and speculations. In other words, resistance and distrust can quickly gain traction in a climate of uncertainty, in which actors fear the unknown consequences of change (e.g., Erwin and Garman 2010; Iverson 1996; Oreg 2006; Palmer et al. 2016; Piderit 2000).

We aim to reveal subjective representations of HM held by different stakeholder groups either directly involved or not involved in the HM pilot project. We refer to the social representations theory by Serge Moscovici (Moscovici 1963; also see Stark et al. 2017) and investigate implicit attitudes and beliefs about HM using free associations tasks and Likert-type survey items (for free association tasks see, for instance, Olsen et al. 2018). We assume that those employees in tax administrations and enterprises who are directly involved in HM feel sufficiently informed and, thus, perceive the change more positively as compared to non-involved people.

\section{Method}

\subsection{Participants}

We assess subjective representations of HM in three different types of organizations, namely the Austrian tax authorities, companies participating in the HM program, and companies not participating in HM. Employees of the following groups were invited to participate in the online survey:

(a) Employees of the tax administration responsible for implementing HM or otherwise directly involved in the project,

(b) employees of the tax administration who were not directly involved in HM, 
(c) employees of companies participating in the project who were responsible for HM matters,

(d) employees of participating companies who were not involved in HM processes, and

(e) employees of companies which were not taking part in the HM project.

To assess changes over time, we collected data at up to three points in time over the course of the project. Employees of the tax administration participated in three waves of data collection (April 2013, May 2014, and October 2015). On part of companies participating in the HM project (HM companies), thirteen company groups comprising 200 subsidiaries took part in the pilot project. Company groups entered the HM project at different points in time over the course of the pilot project. Therefore, employees of HM companies received the first invitation to the survey in the first 6 months after their companies entered the project, and a second invitation approximately 2 years after the first survey. The first surveys of HM companies were completed in Spring-Summer 2013, while the last follow-up surveys were completed in January 2016. One company group entered the project in 2016 and could, therefore, not participate in the survey. Employees of nonparticipating companies were contacted once in November 2015.

The survey was distributed to preselected groups of employees in their particular organizations who had experience in tax matters. With regard to the Austrian tax authorities, the Austrian auditing unit for large businesses and tax offices responsible for large businesses were involved in implementing and maintaining the HM project. We contacted tax officials and auditors, employees of the legal departments, as well as managing directors and invited them to participate in the survey. With regard to HM companies that were part of the HM project, we asked managers to provide email addresses of their employees involved in tax matters in their company. To reach out to non-participating companies (non-HM companies) similar to the participating companies with respect to business size, we sent survey invitations to Austria's 550 largest companies, asking their management to forward the survey to up to ten employees who were responsible for tax matters in their company.

Overall, we sent out 4495 invitations and received 1136 completed or partly completed surveys (see Table 1 for summary statistics). At the first wave of data collection, 1251 invitations to complete the survey were sent out to tax officials; the response rate was $30.38 \%$. At the second and third wave, the response rate amounted to $21.0 \%$ (out of 1283 invitations) and $21.13 \%$ (out of 1235 invitations), respectively. $57.96 \%$ of 88 invited employees of HM-enterprises responded at the first wave, and $36 \%$ (out of 85 invitations) at the second wave. Overall, 550 invitations were sent out to non-HM-enterprises' general management, who invited up to ten employees to participate, which resulted in 141 completed surveys. Regarding the participants' positions in their organizations, 321 (28\%) held management positions and $815(72 \%)$ were employees at lower levels. On average, participants had been employed by their organizations for 22.83 years $(\mathrm{SD}=10.50$, median $=25$ years $)$. 


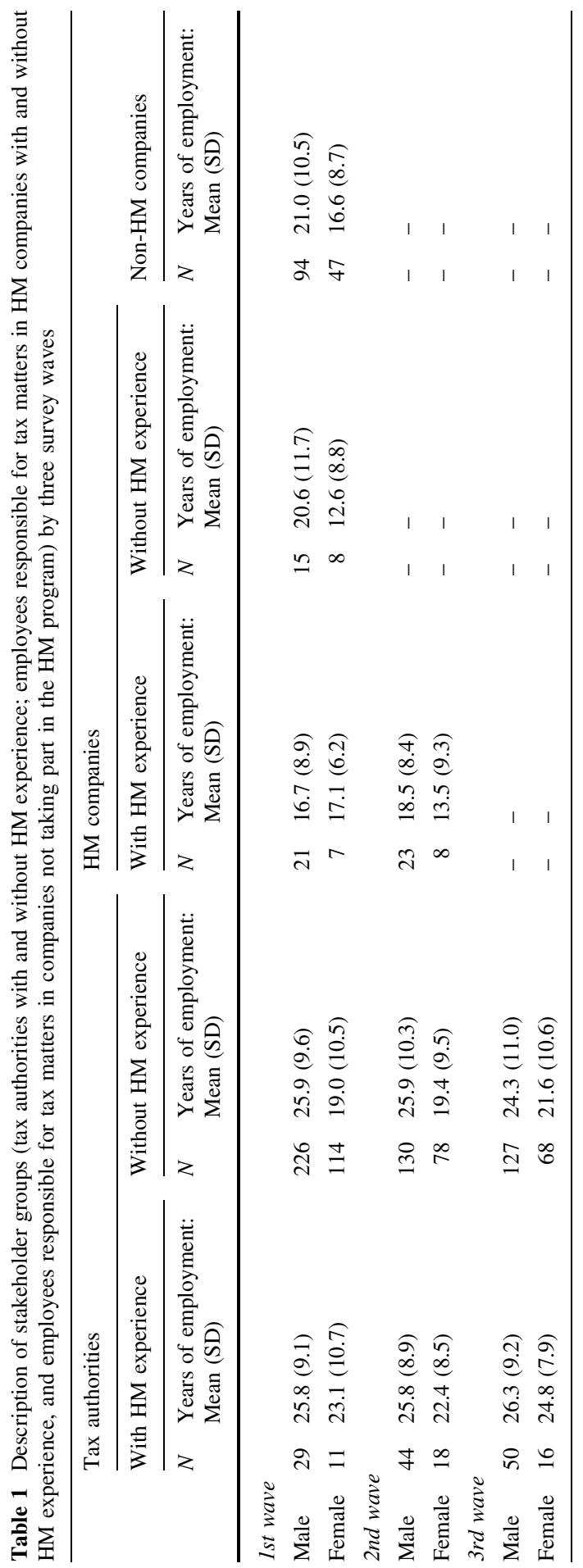




\subsection{Material}

The survey was administered online in German and consisted of three parts. The first section covered information about the goal of the survey and a small number of demographic questions. For anonymity reasons, we asked respondents to only indicate their general position and their years of employment in the organization as well as their gender. To determine their actual involvement in the project, employees of HM companies and of tax authorities were asked to indicate whether they had direct experience with the HM pilot project. The second section consisted of a free association task. Participants were asked to provide up to ten associations that spontaneously came to their mind in response to the term "Horizontal Monitoring". Subsequently, we asked them to rate their own associations as either positive, neutral, or negative.

The third section of the survey comprised five scales that assessed subjective feelings of being informed about HM, attitudes toward HM, identification with HM, confidence in one's own skills to handle HM processes, and subjectively expected effects of HM. Overall, the scales consisted of 30 items, all of which were phrased as statements (see Table 6 in Appendix 1 for the complete questionnaire). Topics and items were jointly developed with the Austrian Ministry of Finance. Participants were asked to read the statements and to indicate their agreement on a scale ranging from 1 (not at all) to 9 (completely). To prevent arbitrary ratings, participants were also given the opportunity to mark the alternative "no answer". The survey followed the same structure for all stakeholder groups. For employees of companies not involved in the HM project, some items explicitly dealing with direct participation in the HM project were removed from the questionnaire (see Table 6 in Appendix 1).

Item analyses showed excellent internal consistency of all five scales, and thus, high reliability (see Table 2 for summary statistics). Items of each scale were

Table 2 Means and standard deviations of survey scales, inter-correlations, and internal consistencies (Cronbach alpha)

\begin{tabular}{llllllll}
\hline & Scale & $M(\mathrm{SD})$ & 1 & 2 & 3 & 4 & $\begin{array}{c}\text { Cronbach } \\
\text { alpha }\end{array}$ \\
\hline 1 & Information (5 items) & $4.45(2.57)$ & - & & & .96 \\
2 & Attitude (10 items) & $5.64(1.95)$ & .315 & - & & .92 \\
3 & Identification (5 items) & $5.62(2.40)$ & .429 & .773 & - & .95 \\
4 & Skills (5 items) & $6.07(2.13)$ & .519 & .515 & .715 & - & .88 \\
5 & Effects (5 items) & $5.84(2.05)$ & .376 & .789 & .750 & .594 & .87 \\
\hline
\end{tabular}

All correlations are significant at $p<.01$. Survey scales were constructed by calculating the mean response to the items in each scale as displayed in Table 6 in Appendix 1. Values express average agreement on a nine-step scale, ranging from 1 (not at all) to 9 (completely) 
aggregated to individual mean scores. In light of the no-answer option and the high internal consistency of all scales, all participants who answered at least two out of five (or four out of ten) items for each scale were included in the analyses of the survey scales.

\subsection{Procedure}

Employees of the tax authorities and of involved companies received personal invitations to complete the survey sent by email. Participation in the survey was voluntary for all invitees. Invitations for employees in non-involved companies were sent by letters addressed to the companies' management. Recipients of these letters were asked to forward the invitation to up to ten employees in the company who were responsible for tax matters.

Due to the sensitive topic and special concerns about participants' anonymity, responses could not be matched across the different survey waves. In the statistical analyses, we therefore treated all samples at the different waves of data collection as independent. This represents a methodological shortcoming limiting the interpretation of time effects.

\section{Results}

\subsection{Free associations with the stimulus "Horizontal Monitoring"}

Participants generated a vast variety of associations in response to the stimulus term "Horizontal Monitoring" (total number of associations by all stakeholder groups and over all survey waves $=4732$, number of unique associations $=3000$ ). Participants who completed the association task produced on average 4.56 associations $\left(\mathrm{SD}=2.42\right.$, median $=4, Q_{1}=3, Q_{3}=6$ ). Tax officials involved in the HM project produced on average 5.06 associations $(\mathrm{SD}=2.35$, median $=5$, $Q_{1}=3, Q_{3}=6$ ) associations; those not involved produced on average 4.51 $\left(\mathrm{SD}=2.51\right.$, median $\left.=4, Q_{1}=3, Q_{3}=6\right)$. HM company employees directly involved in HM produced on average $5.29\left(\mathrm{SD}=1.75\right.$, median $=5.5, Q_{1}=4$, $Q_{3}=6$ ); those not directly involved produced on average 5.08 ( $\mathrm{SD}=1.61$, median $=5, Q_{1}=4, Q_{3}=6$ ). Non-HM company employees produced 3.77 associations $\left(\mathrm{SD}=2.13\right.$, median $\left.=4, Q_{1}=2, Q_{3}=5\right)$.

First, we cleared the list of associations by correcting spelling errors and converting adjectives and verbs to nouns. Second, in cooperation with the Austrian tax authorities, we inductively developed a categorization system that fits the associations (Table 3). Third, four research assistants indepently categorized the associations along the inductively developed categorization system. Inter-rater reliability (Cohen's kappa) ranged from .47 to .60 . If associations had been assigned to different categories by the raters, the raters discussed until they reached consensus about assignments. Table 3 shows the categories and their frequencies by organizations and HM involvement. It should be noted that in the analysis of 
Table 3 Frequencies of free associations to the stimulus "Horizontal Monitoring" by categories and stakeholder groups (absolute counts and relative frequencies within groups in parentheses)

\begin{tabular}{|c|c|c|c|c|c|c|}
\hline \multirow[t]{2}{*}{ Category } & \multicolumn{2}{|c|}{ Tax authorities } & \multicolumn{2}{|c|}{ HM companies } & \multirow{2}{*}{$\begin{array}{l}\text { Non-HM } \\
\text { companies }\end{array}$} & \multirow[t]{2}{*}{ Total } \\
\hline & $\begin{array}{l}\text { With HM } \\
\text { experience }\end{array}$ & $\begin{array}{l}\text { Without } \\
\text { HM } \\
\text { experience }\end{array}$ & $\begin{array}{l}\text { With HM } \\
\text { experience }\end{array}$ & $\begin{array}{l}\text { Without } \\
\text { HM } \\
\text { experience }\end{array}$ & & \\
\hline Cooperation & $118(.15)$ & $426(.14)$ & $66(.19)^{+}$ & $20(.16)$ & $89(.19)^{+}$ & $719(.15)$ \\
\hline $\begin{array}{l}\text { Legal/planning } \\
\text { certainty }\end{array}$ & $67(.09)$ & $233(.08)^{--}$ & $55(.16)^{++}$ & $25(.19)^{++}$ & $88(.19)^{++}$ & $468(.10)$ \\
\hline Elements of HM & $55(.07)$ & $296(.10)^{+}$ & $22(.06)$ & $7(.05)$ & $29(.06)^{-}$ & $409(.09)$ \\
\hline Timeliness & $56(.07)$ & $177(.06)^{-}$ & $32(.09)$ & $17(.13)^{++}$ & $45(.10)^{+}$ & $327(.07)$ \\
\hline Skepticism & $41(.05)$ & $205(.07)^{++}$ & $6(.02)^{--}$ & $0(.00)^{--}$ & $14(.03)^{-}$ & $266(.06)$ \\
\hline Saving of resources & $44(.06)$ & $139(.05)^{-}$ & $33(.09)^{++}$ & $18(.14)^{++}$ & $29(.06)$ & $263(.06)$ \\
\hline Openness/transparency & $71(.09)^{++}$ & $129(.04)^{--}$ & $23(.06)$ & $17(.13)^{++}$ & $16(.03)^{-}$ & $256(.05)$ \\
\hline Tax compliance & $39(.05)$ & $165(.05)$ & $5(.01)^{--}$ & $5(.04)$ & $22(.05)$ & $236(.05)$ \\
\hline Control & $17(.02)^{--}$ & $152(.05)$ & $10(.03)$ & $1(.01)-$ & $41(.09)^{++}$ & $221(.05)$ \\
\hline Trust & $53(.07)^{++}$ & $129(.04)$ & $29(.08)^{++}$ & $6(.05)$ & $3(.01)^{--}$ & $220(.05)$ \\
\hline Change & $51(.06)^{++}$ & $114(.04)$ & $10(.03)$ & $1(.01)^{-}$ & $8(.02)^{-}$ & $184(.04)$ \\
\hline Support & $28(.04)$ & $109(.04)$ & $24(.07)^{++}$ & $5(.04)$ & $15(.03)$ & $181(.04)$ \\
\hline Extra resources & $24(.03)$ & $138(.05)^{+}$ & $9(.03)$ & $0(.00)^{-}$ & $8(.02)^{-}$ & $179(.04)$ \\
\hline Justice & $27(.03)$ & $85(.03)$ & $8(.02)$ & $2(.02)$ & $12(.03)$ & $134(.03)$ \\
\hline HM-development & $25(.03)$ & $83(.03)$ & $8(.02)$ & $2(.02)$ & $8(.02)$ & $126(.03)$ \\
\hline Stakeholder & $15(.02)$ & $78(.03)^{+}$ & $0(.00)^{--}$ & $0(.00)^{-}$ & $8(.02)$ & $101(.02)$ \\
\hline Disapproval & $9(.01)$ & $79(.03)^{++}$ & $1(.00)^{-}$ & $0(.00)$ & $0(.00)^{--}$ & $89(.02)$ \\
\hline Injustice & $8(.01)$ & $62(.02)^{+}$ & $0(.00)^{-}$ & $0(.00)$ & $2(.00)^{-}$ & $72(.02)$ \\
\hline Lack of information & $7(.01)$ & $46(.02)$ & $1(.00)^{-}$ & $0(.00)$ & $8(.02)$ & $62(.01)$ \\
\hline Corruption & $6(.01)$ & $4(.00)^{-}$ & $1(.00)$ & $0(.00)$ & $0(.00)^{-}$ & $52(.01)$ \\
\hline Legal issues & $7(.01)$ & $35(.01)$ & $4(.01)$ & $0(.00)$ & $3(.01)$ & $49(.01)$ \\
\hline Expertise & $7(.01)$ & $28(.01)$ & $4(.01)$ & $2(.02)$ & $2(.00)$ & $43(.01)$ \\
\hline Tax evasion & $0(.00)^{-}$ & $21(.01)^{+}$ & $0(.00)$ & $0(.00)$ & $1(.00)$ & $22(.00)$ \\
\hline $\begin{array}{l}\text { Communication } \\
\text { problem }\end{array}$ & $1(.00)$ & $9(.00)$ & $0(.00)$ & $0(.00)$ & $0(.00)$ & $10(.00)$ \\
\hline Else & $11(.01)$ & $35(.01)$ & $3(.01)$ & $1(.01)$ & $8(.02)$ & $58(.01)$ \\
\hline Total & 787 & 3018 & 354 & 129 & 459 & 4747 \\
\hline
\end{tabular}

Signs $(++,+,-,--)$ indicate whether an association category was observed more or less frequently than expected under the assumption of a uniform distribution of each association-category among groups (analysis based on standard residuals: ${ }^{+} Z>1.69,{ }^{++} Z>2.58,{ }^{-} Z<1.69,{ }^{--} Z<2.58$ )

associations, we did not consider survey waves due to low frequencies in some stakeholder groups.

The most frequent category contains associations that describe aspects of cooperation between companies and tax authorities, such as partnership, open dialog, or cooperation. Cooperation was associated with HM significantly more 
often by employees of companies involved in the project and, interestingly, also by employees of companies not participating in $\mathrm{HM}$ at all. As compared to employees not engaged in HM, tax officials who were directly dealing with HM mentioned significantly more associations related to openness and transparency, trust, and change. Those not involved in the project had less associations about legal and planning certainty, timeliness, and saving resources and produced more terms expressing skepticism, excessive use of resources, disapproval, injustice, and evasion. Category frequencies show that direct involvement in HM is clearly connected with more positive attitudes, while tax officials not directly involved are more skeptical and have more concerns regarding injustice and required financial and work resources.

Also, in companies involved in HM, employees dealing with HM expressed generally more positive terms than employees not involved in the project (e.g., cooperation, trust, and support). However, differences between involved and noninvolved employees are less pronounced than in the samples of tax officials. Employees of companies not participating in the HM program showed rather positive representations, besides the assumption that there is more control of their business activities by the tax authorities.

We conducted a correspondence analysis based on the frequencies presented in Table 3. Using the cross-tabulated frequencies of the categorized associations, this method reveals the underlying structure of the data and creates a dimensional map of the association categories and the five stakeholder groups (Greenarcre 2007; Whitlark and Smith 2001). The analysis yielded a two-dimensional structure. Dimension 1 contributed $58.8 \%$ and dimension 2 contributed $28.8 \%$ to the inertia. As Fig. 1 shows, dimension 1 is best explained by the left- and rightmost categories: The left pole is characterized by advantages of HM (legal/planning certainty, saving of resources, timeliness, and openness/transparency), the right pole contains disadvantages and concerns (increased evasion, injustice, corruption, need of extra resources). While employees of HM companies are located at the pole of advantages, tax officials not directly involved in $\mathrm{HM}$ are closest to the pole of disadvantages. The second dimension ranges from trust and openness/transparency located at the top of the diagram to control and lack of information appearing at the bottom. On this dimension, tax officials directly involved in HM and employees of HM companies are located at the trust pole, whereas non-HM company employees are closest to the control pole.

Stakeholder groups and association categories, represented in Fig. 1, can also be interpreted as spatial distances. The more frequently a combination of associations and groups appeared in the data, the closer these variables are located to each other in the map (Abdi 2007; Greenacre 1991). The map displayed in Fig. 1 shows that tax authorities directly involved in the HM project and employees of HM companies hold positive representation of HM: openness, transparency, trust, saving of resources, support, and expertise are association categories located closely to these three samples. Tax authorities not directly involved in the project are closer to the association categories indicating disapproval, injustice, legal issues, and tax evasion, and lack of information, and communication problems. Finally, the group of employees of companies not involved in HM seem to show a less specific pattern 


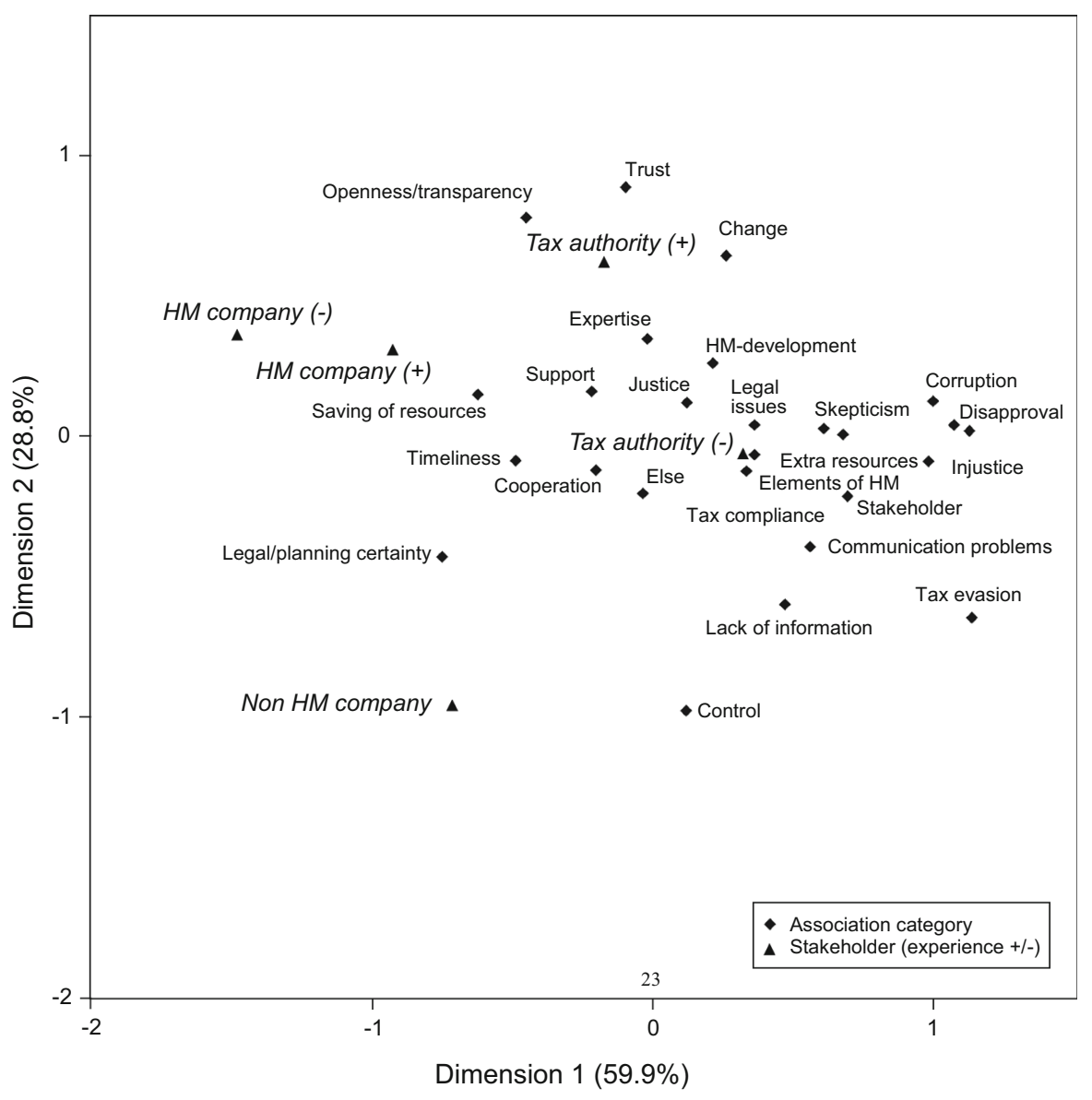

Fig. 1 Two-dimensional solution of correspondence analysis of free association categories by stakeholder groups

of associations. Overall, the association task shows that direct involvement in the HM project is connected to positive representations.

\subsection{Evaluation of free associations to the stimulus "Horizontal Monitoring"}

Participants rated each of their associations either as negative, neutral, or positive. The average rating of a participant's associations-termed polarity indexrepresents an index of implicit attitudes toward HM. The polarity index is expressed by the difference between the numbers of positive and negative evaluations, divided by the sum of all evaluations per participant (de Rosa 1995). It ranges from -1 to +1 , with negative values indicating more negative attitudes and values closer to +1 reflecting positive attitudes. A second index, the neutrality index, is derived from the sum of neutral evaluations produced by a participant 
Table 4 Neutrality and polarity indices by stakeholder groups (means and SDs)

\begin{tabular}{lllllll}
\hline & \multicolumn{3}{l}{ Tax authorities } & & & HM companies \\
\cline { 2 - 3 } $\begin{array}{l}\text { With HM } \\
\text { experience } \\
(N=157)\end{array}$ & $\begin{array}{l}\text { Without HM } \\
\text { experience } \\
(N=662)\end{array}$ & & $\begin{array}{l}\text { With HM } \\
\text { experience } \\
(N=57)\end{array}$ & $\begin{array}{l}\text { Without HM } \\
\text { experience } \\
(N=24)\end{array}$ & $\begin{array}{l}\text { Non-HM } \\
\text { companies } \\
(N=122)\end{array}$ \\
\hline $\begin{array}{l}\text { Polarity } \\
\text { Neutrality }\end{array}$ & $0.51(0.57)^{\mathrm{b}}$ & $0.32(0.63)^{\mathrm{c}}$ & & $0.80(0.27)^{\mathrm{a}}$ & $0.87(0.16)^{\mathrm{a}}$ & $0.59(0.58)^{\mathrm{b}}$ \\
\hline
\end{tabular}

Superscripts $(a, b, c)$ indicate significant differences, i.e., means with the same superscript do not differ significantly $(p>.05)$. The polarity index represents the implicit attitude towards HM as reflected in the associations; it is calculated by dividing the difference between the number of positive and negative associations by the total number of associations made by a participant. The neutrality index reflects how many neutral associations a participant made in relation to the total number of associations

divided by the number of all evaluations produced by the respective participants. It ranges from 0 to 1 , with higher values indicating more neutral associations.

We conducted multivariate analyses of variance (MANOVA) with polarity index and neutrality index as dependent variables and the five stakeholder groups as independent factor. The analysis revealed a significant effect of $F(8,2034)=9.739$; $p<.001 ; \eta^{2}=.037$. Univariate analyses, conducted separately for polarity and neutrality indices, showed significant effects for polarity $(F(4)=17.757 ; p<.001$; $\left.\eta^{2}=.065\right)$ and neutrality $\left(F(4)=7.053 ; p<.001 ; \eta^{2}=.027\right)$. As means in Table 4 show, employees of HM companies hold the most positive implicit associations. Tax officials with direct HM experience and employees of non-HM companies hold less favorable attitudes as compared to employees of HM companies, but the most negative implicit attitudes were measured in the group of tax officials without HM experience. As compared to the other stakeholder groups, in this latter group we also observed the highest number of neutral associations.

\subsection{Analysis of survey scales}

Table 5 displays means of the five scales (information, attitude, identification, skills, and effects) by stakeholder groups and survey waves. As displayed in Table 5, data were available from directly involved and not involved tax officials for three waves, from employees of HM companies for two waves, and from non-HM companies for one wave. For this reason, we conducted the analysis in three steps. ${ }^{1}$ First, we compared all five groups at the first survey wave and found significant differences between the groups. Second, we assessed changes over time among tax officials and found a significant difference between participants involved and not involved in the HM project, but not between survey waves. Third, we assessed change over time

\footnotetext{
${ }^{1}$ We conducted two additional sets of analyses as robustness checks: First, we constructed the scales using only items which were available for all groups (see Table 6 in Appendix 1) and repeated the three analyses. Second, we included the control variables gender, position (management vs. other), and years of employment in the organization into the analyses. Both robustness checks yielded results virtually identical to the main analyses.
} 
Table 5 Means and standard deviations of survey scales by survey wave and stakeholder groups (tax authorities with or without HM experience; HM company employees with or without HM exerience, and employees of companies not taking part in the HM program)

\begin{tabular}{|c|c|c|c|c|c|}
\hline & \multicolumn{2}{|c|}{ Tax authorities } & \multicolumn{2}{|c|}{ HM companies } & \multirow{2}{*}{$\begin{array}{l}\text { Non-HM } \\
\text { companies }\end{array}$} \\
\hline & $\begin{array}{l}\text { With HM } \\
\text { experience }\end{array}$ & $\begin{array}{l}\text { Without HM } \\
\text { experience }\end{array}$ & $\begin{array}{l}\text { With HM } \\
\text { experience }\end{array}$ & $\begin{array}{l}\text { Without HM } \\
\text { experience }\end{array}$ & \\
\hline \multicolumn{6}{|l|}{ 1st wave } \\
\hline$N$ & 39 & 275 & 25 & 22 & 111 \\
\hline Information & $6.88(2.22)^{\mathrm{a}}$ & $4.30(2.21)^{\mathrm{b}}$ & $7.39(1.32)^{\mathrm{a}}$ & $7.19(0.95)^{\mathrm{a}}$ & $2.57(2.23)^{\mathrm{c}}$ \\
\hline Attitude & $5.81(2.10)^{\mathrm{b}}$ & $5.00(1.84)^{\mathrm{c}}$ & $7.95(0.95)^{\mathrm{a}}$ & $7.50(1.09)^{\mathrm{a}}$ & $6.43(1.48)^{\mathrm{b}}$ \\
\hline Identification & $6.66(2.40)^{\mathrm{b}}$ & $4.90(2.29)^{\mathrm{c}}$ & $8.08(1.29)^{\mathrm{a}}$ & $7.90(1.01)^{\mathrm{a}}$ & $6.38(2.00)^{\mathrm{b}}$ \\
\hline Skills & $7.14(1.60)^{\mathrm{b}}$ & $5.22(2.04)^{\mathrm{c}}$ & $8.17(0.63)^{\mathrm{a}}$ & $7.64(1.44)^{\mathrm{a}, \mathrm{b}}$ & $6.96(1.69)^{\mathrm{b}}$ \\
\hline Effects & $6.46(2.00)^{\mathrm{b}}$ & $5.10(2.03)^{\mathrm{c}}$ & $7.74(0.80)^{\mathrm{a}}$ & $8.00(1.14)^{\mathrm{a}}$ & $6.40(1.77)^{b}$ \\
\hline \multicolumn{6}{|l|}{ 2nd wave } \\
\hline$N$ & 57 & 168 & 31 & - & - \\
\hline Information & $7.14(1.75)$ & $4.67(2.20)$ & $7.19(0.96)$ & - & - \\
\hline Attitude & $6.51(1.54)$ & $5.30(1.80)$ & $7.88(0.91)$ & - & - \\
\hline Identification & $6.91(1.76)$ & $5.14(2.21)$ & $8.04(1.31)$ & - & - \\
\hline Skills & $7.17(1.45)$ & $5.65(2.06)$ & $8.07(0.78)$ & - & - \\
\hline Effects & $6.71(1.41)$ & $5.56(1.90)$ & $8.04(1.11)$ & - & - \\
\hline \multicolumn{6}{|l|}{$3 r d$ wave } \\
\hline$N$ & 59 & 150 & - & - & - \\
\hline Information & $6.87(1.70)$ & $4.32(2.03)$ & - & - & - \\
\hline Attitude & $6.27(1.80)$ & $5.14(2.00)$ & - & - & - \\
\hline Identification & $6.68(2.03)$ & $4.70(2.28)$ & - & - & - \\
\hline Skills & $7.11(1.46)$ & $5.49(2.02)$ & - & - & - \\
\hline Effects & $6.59(1.73)$ & $5.58(2.06)$ & - & - & - \\
\hline
\end{tabular}

Superscripts $(a, b, c)$ indicate significant differences between stakeholder groups at the first survey wave, i.e., mean values with the same superscript do not differ significantly $(p>.05)$. Survey scales were constructed by calculating the mean response to the items in each scale as displayed in Table 6 in Appendix 1. Values express average agreement on a nine-step scale, ranging from 1 (not at all) to 9 (completely)

among HM company employees; again, we did not observe a significant difference between the survey waves in any of the survey scales.

In the first step of the analysis, we assessed differences in the scales information, attitude, identification, skills, and effects between the five stakeholder groups at the first survey wave (see Table 5, first wave). Since we had only one measurement wave in the group of non-HM company employees, we took into account the responses of the other stakeholder groups which were gained at the first survey wave and conducted a multivariate analysis of variance ${ }^{2}$ with the five scales as the

\footnotetext{
${ }^{2}$ Analyses of variance are commonly used to test whether means of two or more groups differ from each other. Multivariate analyses of variance, however, incorporate multiple dependent variables, thereby simultaneously testing the effects of the independent variables on a set of possibly intercorrelated dependent variables. If a significant effect in a multivariate test is found, we use conventional univariate analyses of variance for each dependent variable to provide a more detailed view on the effects.
} 
dependent variables and the stakeholder group as the independent variable. The analyses revealed a significant effect of $F(20,1864)=19.821 ; p<.001 ; \eta^{2}=.175$. Univariate analysis revealed significant results for all five scales: for information $F(4)=55.201 ; \quad p<.001 ; \quad \eta^{2}=.321 ;$ for attitude $F(4)=33.068 ; \quad p<.001$; $\eta^{2}=.221 ;$ for identification $F(4)=27.645 ; p<.001 ; \eta^{2}=.191 ;$ for skills $F(4)=36.112 ; p<.001 ; \eta^{2}=.236 ;$ and for effects $F(4)=27.451 ; p<.001$; $\eta^{2}=.190$. As means and pairwise comparisons show (see Table 5), employees of HM companies directly involved and not involved in HM activities as well as tax officials involved in HM felt best informed and had the most favorable attitudes. They also identified the most with HM and indicated having high skills and expecting positive effects. Tax officials not directly involved in HM indicated lacking information, having less favorable attitudes, identifying less with HM, having lower skills and not expecting very positive effects. Employees of non-HM companies admitted not being informed about HM; their values in the other scales, however, were quite similar to those of the group of tax officials with HM experience. To confirm group differences on a single-item level, we calculated item means and conducted pairwise comparisons for each item. As shown in Table 7 in Appendix 2, the overall results of the item level analysis are very similar to the pattern found in the scales. In sum, the results support our observations in the analyses of associations.

In the second step, we assessed changes over time among the groups of tax officials with and without experience (see Table 5, first two columns). A multivariate analysis of variance-with the survey scales as dependent variables and HM experience (yes, no) and survey wave $(1,2,3)$ as independent variablesyielded a significant main effect of experience $(F(5,738)=37.589 ; p<.001$; $\left.\eta^{2}=.203\right)$, but no main effect of survey wave $(F(10,1478)=1.511 ; p=.129$; $\left.\eta^{2}=.010\right)$ and no interaction effect $\left(F(10,1478)=.806 ; p=.623 ; \eta^{2}=.005\right)$. As already described above, tax officials with HM experience held more favorable representations than officials not directly involved, and this is true for all three survey waves.

In the third step, we analyzed changes of time in the group of employees of HM companies who were dealing with HM in their company (see Table 5, third column). We conducted another multivariate analysis of variance with the five survey scales as dependent variables and wave $(1,2)$ as the independent factor. The effect of time was far from reaching significance $[F(5,50)=.931 ; p=.469$; $\left.\eta^{2}=.085\right]$.

\section{Conclusions}

The aim of this study was to investigate how $\mathrm{HM}$ as a new paradigm in tax administration is perceived by different stakeholder groups (companies participating in the HM project, tax authorities, and companies not taking part in HM). We assumed that direct experience with the change project fuels positive representations, and assessed whether representations of tax officials change over the course of 3 years. 
We find that HM is perceived significantly more positively by tax officials involved in HM. It is also perceived as highly positive by employees of companies taking part in the HM pilot project, independent of whether the employees were directly dealing with HM procedures in their company or not. This pattern of results was confirmed by the different research methods applied, with contents and evaluations of associations as well as survey scales yielding a homogeneous picture. We also find that representations as captured in the questionnaire remained invariant over time. On the one hand, this suggests that positive perceptions by participants with HM experience formed at the beginning of the process were maintained throughout the period of investigation. On the other hand, this also indicates that tax officials inexperienced in HM remained considerably more skeptical throughout the evaluation period.

These findings are not surprising given that implementing cooperative compliance strategies requires a new mindset within the tax authorities. HM follows a progressive understanding of tax administration and may appear difficult to reconcile with prevailing law for many tax officials who were trained in a "copsand-robbers" tradition. Changing the prevailing mindset may take time to develop and to be accepted. However, as reflected in all three survey waves, tax officials not directly involved in the project indicated that they were not sufficiently informed and, thus, it seems that they developed a high degree of skepticism and disapproval. These results give indications about possible weaknesses of the pilot project that should be addressed when HM will be included in the regular operation of tax administration.

Our results are in line with observations in organizational change processes: people who feel poorly informed and not directly involved in the change process breed skepticism and distrust and react with resistance and low commitment. Evidence from other countries that implemented similar approaches to reach cooperative compliance shows that proactive change management in the form of staff training and commitment is necessary for the projects' success (van der Helvan Dijk and Poolen 2013). Our results support this view and suggest that change management among tax authorities has to be improved in order to promote the acceptance of the new paradigm.

Considering the importance of direct experience with HM, a possible selfselection has to be kept in mind when interpreting differences between participants with and without HM experience. Tax authority employees may have decided to assume responsibility in the project if they were already convinced of their own qualifications and the project's benefits and, of course, the same can be assumed for companies' decisions to participate in the project. Because of anonymity concerns, we could not study changes in perceptions in a within-subjects design, which would have allowed us to draw more reliable conclusions about changes in perceptions with increasing experience. For instance, we cannot exclude that participants who developed less favorable perceptions of HM over time stopped participating in subsequent waves of data collection.

Despite the shortcomings of this study, valuable insights can be gained that should be taken into account in the long-term implementation of HM in Austria. We demonstrate that the paradigm shift from command-and-control to cooperative 
relationships entails questioning the prevailing mindset, especially among tax authorities. We observed that direct contact with the new paradigm is of paramount importance in the process of implementing HM because employees directly involved in the project felt informed and had confidence in their skills to deal with the change in their organizations.

Lack of transparency and the feeling of being poorly informed seem to promote insecurity and skepticism and cause distrust and resistance. Therefore, in order to increase acceptance of HM and the willingness to trust and cooperate, especially during the critical period of implementation, tax administration staff and company employees need to be fully informed about the project, its goals, and its implementation steps. Information must be provided not only to employees directly involved in HM but also to stakeholders outside the project in order to promote the challenging paradigm shift toward cooperative relationships.

Acknowledgements We would like to thank the Austrian Ministry of Finance for collecting the data and for the cooperation throughout the project and the editor and two anonymous reviewers for valuable comments to improve the paper.

Open Access This article is distributed under the terms of the Creative Commons Attribution 4.0 International License (http://creativecommons.org/licenses/by/4.0/), which permits unrestricted use, distribution, and reproduction in any medium, provided you give appropriate credit to the original author(s) and the source, provide a link to the Creative Commons license, and indicate if changes were made.

\section{Appendix 1}

Table 6 Questionnaire

\begin{tabular}{|c|c|c|}
\hline & Original items & English translation \\
\hline \multicolumn{3}{|c|}{ Information } \\
\hline 1. & $\begin{array}{l}\text { Ich bin über Horizontal Monitoring umfassend } \\
\text { informiert }\end{array}$ & $\begin{array}{l}\text { I am fully informed about Horizontal } \\
\text { Monitoring }\end{array}$ \\
\hline 2. & $\begin{array}{l}\text { Die Strategie der Finanzverwaltung betreffend } \\
\text { Horizontal Monitoring ist mir bekannt }\end{array}$ & $\begin{array}{l}\text { I am familiar with the strategy behind } \\
\text { Horizontal Monitoring }\end{array}$ \\
\hline 3. & $\begin{array}{l}\text { Ich bin über die Ziele von Horizontal } \\
\text { Monitoring sehr gut informiert }\end{array}$ & $\begin{array}{l}\text { I am familiar with the goals of Horizontal } \\
\text { Monitoring }\end{array}$ \\
\hline 4. & $\begin{array}{l}\text { Ich kenne den aktuellen Stand des } \\
\text { Pilotprojektes Horizontal Monitoring }\end{array}$ & $\begin{array}{l}\text { I know the current status of the Horizontal } \\
\text { Monitoring project }\end{array}$ \\
\hline 5. & $\begin{array}{l}\text { Ich bin mit dem Ablauf des Horizontal } \\
\text { Monitoring Prozesses voll vertraut }\end{array}$ & $\begin{array}{l}\text { I am familiar with the procedures of the HM } \\
\text { process }\end{array}$ \\
\hline \multicolumn{3}{|c|}{ Attitude } \\
\hline 6. & Ich finde Horizontal Monitoring sehr gut & I believe that HM is a good thing \\
\hline 7. & Horizontal Monitoring entspricht dem Zeitgeist & $\begin{array}{l}\text { Horizontal Monitoring corresponds to the } \\
\text { zeitgeist }\end{array}$ \\
\hline 8. & $\begin{array}{l}\text { Horizontal Monitoring bringt einen } \\
\text { Imagegewinn für alle Beteiligten }\end{array}$ & $\begin{array}{l}\text { Horizontal Monitoring improves the image of } \\
\text { all stakeholders }\end{array}$ \\
\hline
\end{tabular}


Table 6 continued

\begin{tabular}{|c|c|}
\hline & Original items \\
\hline 9. & $\begin{array}{l}\text { Horizontal Monitoring steht für eine gute } \\
\text { Zusammenarbeit aller Beteiligten }\end{array}$ \\
\hline 10. & $\begin{array}{l}\text { Ich bin überzeugt, dass Horizontal Monitoring } \\
\text { die bisherige Arbeit aller Beteiligten } \\
\text { erleichtert }\end{array}$ \\
\hline $11 .^{\dagger}$ & $\begin{array}{l}\text { Der Nutzen von Horizontal Monitoring wird } \\
\text { überbewertet }\end{array}$ \\
\hline $12 .^{\dagger}$ & $\begin{array}{l}\text { Die partnerschaftliche Zusammenarbeit } \\
\text { widerspricht der Berufsethik }\end{array}$ \\
\hline 13. $*^{\dagger}$ & $\begin{array}{l}\text { In das Projekt Horizontal Monitoring werden } \\
\text { zu viele Ressourcen investiert }\end{array}$ \\
\hline $14 .^{\dagger}$ & $\begin{array}{l}\text { Langwierige Betriebsprüfungen bleiben durch } \\
\text { Horizontal Monitoring nicht erspart }\end{array}$ \\
\hline $15 .^{\dagger}$ & $\begin{array}{l}\text { Ich bezweifle, dass die Aufgaben im } \\
\text { Zusammenhang mit Horizontal Monitoring } \\
\text { rasch behandelt werden können }\end{array}$ \\
\hline \multicolumn{2}{|r|}{ Identification } \\
\hline 16. & $\begin{array}{l}\text { Ich identifiziere mich sehr mit den Zielen von } \\
\text { Horizontal Monitoring }\end{array}$ \\
\hline 17. & $\begin{array}{l}\text { Ich denke, dass meine Wertvorstellungen mit } \\
\text { denen der Horizontal Monitoring Initiative } \\
\text { der Finanzverwaltung sehr gut zusammen } \\
\text { passen }\end{array}$ \\
\hline
\end{tabular}

18.* Ich bin stolz an einem Prozess mitzuwirken, in dem sich alle Beteiligten als Partner sehen

19.* Ich leiste gerne einen Beitrag zum Gelingen von Horizontal Monitoring

English translation

Horizontal Monitoring stands for good collaboration among all participants

I am convinced that HM facilitates everyone's work

The benefits of Horizontal Monitoring are overrated

The cooperative partnership contradicts the professional ethics

Too many resources are spent for the HM project

Horizontal Monitoring cannot prevent lengthy tax audits

I doubt whether tasks related to HM can be carried out in a timely manner

I strongly identify with the goals of Horizontal Monitoring

I believe my values are compatible with the Horizontal Monitoring project

I am proud to be part of a process in which all participants are regarded as partners

I am happy to contribute to the success of Horizontal Monitoring

I regard HM as an enrichment of my day-today work

I feel qualified for an active participation in Horizontal Monitoring

Monitoring fühle ich mich sehr gut qualifiziert

22.* Mein Fachwissen für Horizontal Monitoring ist auf dem aktuellen Stand

23.* Es ist mir lieber im Horizontal Monitoring Prozess mit allen Beteiligten zu kooperieren, als alleine bei Prüfungen mitzuwirken

24. Ich traue mir zu, im Horizontal Monitoring Prozess professionell mitwirken zu können

25. Ich arbeite gerne in Teams, so wie es im Horizontal Monitoring vorgesehen ist

Effects

26. Ich bin überzeugt, dass durch Horizontal Monitoring die Steuerehrlichkeit steigt
My professional expertise and know-how concerning Horizontal Monitoring are up to date

I prefer to cooperate with all stakeholders in the Horizontal Monitoring process, instead of working alone in tax audits

I feel confident working professionally in the Horizontal Monitoring process

I like working in teams, as it is intended in Horizontal Monitoring

I am convinced that Horizontal Monitoring increases tax compliance 
Table 6 continued

\begin{tabular}{|c|c|c|}
\hline & Original items & English translation \\
\hline 27. & $\begin{array}{l}\text { Ich bin überzeugt, dass alle Beteiligten im } \\
\text { Horizontal Monitoring alle relevanten } \\
\text { Unterlagen offen legen }\end{array}$ & $\begin{array}{l}\text { I am convinced that all participants in } \\
\text { Horizontal Monitoring disclose all relevant } \\
\text { documents }\end{array}$ \\
\hline 28. & $\begin{array}{l}\text { Ich bin überzeugt, dass die Finanzverwaltung } \\
\text { im Rahmen von Horizontal Monitoring rasch } \\
\text { und kompetent Rechtsauskünfte erteilt }\end{array}$ & $\begin{array}{l}\text { I am convinced that in Horizontal Monitoring } \\
\text { the tax authorities give accurate information } \\
\text { in a timely manner }\end{array}$ \\
\hline 29. & $\begin{array}{l}\text { Ich sehe einen Vorteil für Unternehmen, wenn } \\
\text { sie gemeinsam mit der Finanzverwaltung das } \\
\text { interne Steuerkontrollsystem einrichten und } \\
\text { weiterentwickeln }\end{array}$ & $\begin{array}{l}\text { Companies benefit from establishing and } \\
\text { developing internal tax control frameworks } \\
\text { in cooperation with the tax authorities }\end{array}$ \\
\hline 30. & $\begin{array}{l}\text { Horizontal Monitoring bringt Planungs- und } \\
\text { Rechtssicherheit für alle Beteiligten }\end{array}$ & $\begin{array}{l}\text { Horizontal Monitoring provides legal and } \\
\text { planning security for all stakeholders }\end{array}$ \\
\hline
\end{tabular}

Responses were given on a nine-point scale expressing agreement to the items from 1 (not at all) to 9 (completely)

*Items removed from the questionnaire for companies not participating in the HM project

$\dagger$ Items responses were reversed to construct the scale

\section{Appendix 2}

Table 7 Means and standard deviations of survey items by stakeholder groups at the first survey wave

\begin{tabular}{|c|c|c|c|c|c|}
\hline \multirow[t]{2}{*}{ Items } & \multicolumn{2}{|l|}{ Tax authorities } & \multicolumn{2}{|c|}{ HM companies } & \multirow[b]{2}{*}{$\begin{array}{l}\text { Non-HM } \\
\text { companies } \\
(N=95-111)\end{array}$} \\
\hline & $\begin{array}{l}\text { With HM } \\
\text { experience } \\
(N=32-39)\end{array}$ & $\begin{array}{l}\text { Without HM } \\
\text { experience } \\
(N=222-274)\end{array}$ & $\begin{array}{l}\text { With HM } \\
\text { experience } \\
(N=23-25)\end{array}$ & $\begin{array}{l}\text { Without HM } \\
\text { experience } \\
(N=18-22)\end{array}$ & \\
\hline \multicolumn{6}{|c|}{ Information } \\
\hline 1. & $7.41(2.09)^{\mathrm{a}}$ & $4.68(2.40)^{\mathrm{b}}$ & $7.72(1.34)^{\mathrm{a}}$ & $7.45(1.06)^{\mathrm{a}}$ & $2.91(2.70)^{\mathrm{c}}$ \\
\hline 2. & $7.15(2.28)^{\mathrm{a}}$ & $5.27(2.53)^{\mathrm{b}}$ & $7.48(1.58)^{\mathrm{a}}$ & $7.68(1.04)^{\mathrm{a}}$ & $2.78(2.59)^{\mathrm{c}}$ \\
\hline 3. & $7.05(2.37)^{\mathrm{a}}$ & $4.75(2.50)^{\mathrm{b}}$ & $7.75(1.33)^{\mathrm{a}}$ & $7.59(0.91)^{\mathrm{a}}$ & $2.93(2.63)^{\mathrm{c}}$ \\
\hline 4. & $6.41(2.98)^{\mathrm{a}}$ & $3.33(2.48)^{\mathrm{b}}$ & $6.71(1.92)^{\mathrm{a}}$ & $6.71(1.90)^{\mathrm{a}}$ & $2.14(2.01)^{\mathrm{c}}$ \\
\hline 5. & $6.38(2.62)^{\mathrm{a}}$ & $3.48(2.39)^{\mathrm{b}}$ & $7.20(1.47)^{\mathrm{a}}$ & $6.45(1.50)^{\mathrm{a}}$ & $2.10(2.04)^{\mathrm{c}}$ \\
\hline \multicolumn{6}{|c|}{ Attitude } \\
\hline 6. & $6.39(2.66)^{\mathrm{a}}$ & $4.85(2.52)^{\mathrm{b}}$ & $8.16(1.49)^{\mathrm{a}}$ & $7.86(1.32)^{\mathrm{a}}$ & $6.98(1.92)^{\mathrm{a}}$ \\
\hline 7. & $6.59(2.38)^{\mathrm{a}, \mathrm{b}}$ & $5.83(2.67)^{\mathrm{b}}$ & $8.42(.97)^{\mathrm{a}}$ & $7.62(2.01)^{\mathrm{a}}$ & $6.79(1.91)^{\mathrm{a}}$ \\
\hline 8. & $6.51(2.63)^{\mathrm{a}}$ & $5.06(2.70)^{\mathrm{b}}$ & $7.67(1.20)^{\mathrm{a}}$ & $7.68(1.92)^{\mathrm{a}}$ & $6.57(2.11)^{\mathrm{a}}$ \\
\hline 9. & $7.21(2.48)^{\mathrm{b}, \mathrm{c}}$ & $6.04(2.55)^{\mathrm{d}}$ & $8.40(1.15)^{\mathrm{a}}$ & $8.33(0.80)^{\mathrm{a}, \mathrm{b}}$ & $7.23(2.06)^{\mathrm{c}}$ \\
\hline 10. & $4.87(2.65)^{\mathrm{b}}$ & $4.28(2.40)^{\mathrm{b}}$ & $7.60(1.73)^{\mathrm{a}}$ & $7.43(1.60)^{\mathrm{a}}$ & $6.45(2.19)^{\mathrm{a}}$ \\
\hline $11 .^{\dagger}$ & $5.90(2.62)^{\mathrm{c}}$ & $5.70(2.53)^{\mathrm{c}}$ & $2.29(1.60)^{\mathrm{a}}$ & $2.45(1.71)^{\mathrm{a}}$ & $4.07(2.18)^{\mathrm{b}}$ \\
\hline $12 .^{\dagger}$ & $3.10(2.74)^{\mathrm{b}}$ & $4.20(2.75)^{\mathrm{c}}$ & $1.57(1.47)^{\mathrm{a}}$ & $2.00(1.54)^{\mathrm{a}, \mathrm{b}}$ & $2.07(2.00)^{\mathrm{a}}$ \\
\hline $13 *^{\dagger}$ & $4.43(2.82)^{\mathrm{b}, \mathrm{c}}$ & $4.82(2.46)^{\mathrm{c}}$ & $1.87(1.18)^{\mathrm{a}}$ & $3.21(1.87)^{\mathrm{a}, \mathrm{b}}$ & - \\
\hline $14 .^{\dagger}$ & $4.97(2.83)^{\mathrm{b}}$ & $5.46(2.62)^{\mathrm{b}}$ & $2.68(1.77)^{\mathrm{a}}$ & $2.56(1.62)^{\mathrm{a}}$ & $5.23(2.49)^{\mathrm{b}}$ \\
\hline $15 .^{\dagger}$ & $5.10(2.72)^{\mathrm{c}}$ & $5.48(2.43)^{\mathrm{d}}$ & $2.08(1.00)^{\mathrm{a}}$ & $3.45(2.15)^{\mathrm{b}}$ & $4.71(2.14)^{\mathrm{c}}$ \\
\hline
\end{tabular}


Table 7 continued

\begin{tabular}{|c|c|c|c|c|c|}
\hline \multirow[t]{2}{*}{ Items } & \multicolumn{2}{|l|}{ Tax authorities } & \multicolumn{2}{|l|}{ HM companies } & \multirow[b]{2}{*}{$\begin{array}{l}\text { Non-HM } \\
\text { companies } \\
(N=95-111)\end{array}$} \\
\hline & $\begin{array}{l}\text { With HM } \\
\text { experience } \\
(N=32-39)\end{array}$ & $\begin{array}{l}\text { Without HM } \\
\text { experience } \\
(N=222-274)\end{array}$ & $\begin{array}{l}\text { With HM } \\
\text { experience } \\
(N=23-25)\end{array}$ & $\begin{array}{l}\text { Without HM } \\
\text { experience } \\
(N=18-22)\end{array}$ & \\
\hline \multicolumn{6}{|c|}{ Identification } \\
\hline 16. & $6.28(2.65)^{\mathrm{b}}$ & $4.40(2.47)^{\mathrm{c}}$ & $7.96(1.62)^{\mathrm{a}}$ & $7.81(1.29)^{\mathrm{a}}$ & $5.95(2.27)^{\mathrm{b}}$ \\
\hline 17. & $6.70(2.46)^{\mathrm{b}}$ & $5.10(2.56)^{\mathrm{c}}$ & $8.20(1.41)^{\mathrm{a}}$ & $8.09(1.11)^{\mathrm{a}}$ & $6.80(1.96)^{\mathrm{b}}$ \\
\hline $18 .^{*}$ & $6.75(2.36)^{b}$ & $4.77(2.68)^{\mathrm{c}}$ & $8.24(1.16)^{\mathrm{a}}$ & $8.09(1.54)^{\mathrm{a}}$ & - \\
\hline $19 *^{*}$ & $7.49(2.28)^{\mathrm{a}}$ & $5.80(2.45)^{\mathrm{b}}$ & $8.60(1.22)^{\mathrm{a}}$ & $8.50(0.8)^{\mathrm{a}}$ & - \\
\hline $20 *^{*}$ & $6.56(2.68)^{\mathrm{a}}$ & $4.50(2.65)^{\mathrm{b}}$ & $7.40(1.80)^{\mathrm{a}}$ & $6.90(1.74)^{\mathrm{a}}$ & - \\
\hline \multicolumn{6}{|l|}{ Skills } \\
\hline $21 *^{*}$ & $7.08(2.30)^{\mathrm{a}}$ & $4.93(2.55)^{\mathrm{b}}$ & $7.88(1.13)^{\mathrm{a}}$ & $7.52(1.69)^{\mathrm{a}}$ & - \\
\hline $22 *^{*}$ & $7.36(2.07)^{\mathrm{a}}$ & $4.68(2.58)^{b}$ & $7.92(1.00)^{\mathrm{a}}$ & $6.90(1.81)^{\mathrm{a}}$ & - \\
\hline $23 * *$ & $5.91(2.75)^{\mathrm{b}}$ & $4.80(2.53)^{\mathrm{c}}$ & $8.28(0.98)^{\mathrm{a}}$ & $7.70(1.81)^{\mathrm{a}}$ & - \\
\hline 24. & $7.74(1.98)^{\mathrm{a}}$ & $5.57(2.56)^{\mathrm{c}}$ & $8.44(.71)^{\mathrm{a}}$ & $8.19(1.33)^{\mathrm{a}}$ & $6.66(2.25)^{\mathrm{b}}$ \\
\hline 25. & $7.19(2.40)^{\mathrm{b}}$ & $6.20(2.43)^{\mathrm{c}}$ & $8.32(1.22)^{\mathrm{a}}$ & $8.19(1.44)^{\mathrm{a}, \mathrm{b}}$ & $7.27(1.65)^{\mathrm{b}}$ \\
\hline \multicolumn{6}{|c|}{ Effects } \\
\hline 26. & $5.45(2.75)^{\mathrm{b}}$ & $4.04(2.58)^{\mathrm{c}}$ & $7.44(1.53)^{\mathrm{a}}$ & $8.00(1.21)^{\mathrm{a}}$ & $6.01(2.44)^{\mathrm{b}}$ \\
\hline 27. & $5.39(2.49)^{\mathrm{b}}$ & $3.81(2.48)^{\mathrm{c}}$ & $7.79(0.72)^{\mathrm{a}}$ & $8.05(1.40)^{\mathrm{a}}$ & $5.93(2.44)^{\mathrm{b}}$ \\
\hline 28. & $6.79(2.07)^{\mathrm{a}}$ & $5.32(2.34)^{\mathrm{b}}$ & $7.76(1.27)^{\mathrm{a}}$ & $7.36(1.81)^{\mathrm{a}}$ & $5.79(2.35)^{\mathrm{b}}$ \\
\hline 29. & $7.89(1.66)^{\mathrm{a}, \mathrm{b}}$ & $6.40(2.36)^{\mathrm{c}}$ & $7.72(1.51)^{\mathrm{a}, \mathrm{b}}$ & $8.09(1.06)^{\mathrm{a}}$ & $7.12(1.85)^{\mathrm{b}}$ \\
\hline 30. & $6.82(2.74)^{\mathrm{c}, \mathrm{d}}$ & $6.05(2.54)^{\mathrm{d}}$ & $8.08(1.19)^{\mathrm{a}, \mathrm{b}}$ & $8.48(0.93)^{\mathrm{a}}$ & $7.09(2.02)^{\mathrm{b}, \mathrm{c}}$ \\
\hline
\end{tabular}

Superscripts (a, b, c, d) indicate significant differences between stakeholder groups at the first survey wave, i.e., mean values with the same superscript do not differ significantly $(p>.05)$. Responses were given on a nine-point scale expressing agreement to the items from 1 (not at all) to 9 (completely)

*Items removed from the questionnaire for companies not participating in the HM project

${ }^{\dagger}$ Item responses were reversed to construct the scale, means of original values are shown in this table

\section{References}

Abdi, H. 2007. Multiple correspondence analysis. Encyclopedia of Measurement and Statistics 95 (2): 116-128.

Allingham, M.G., and A. Sandmo. 1972. Income tax evasion: A theoretical analysis. Journal of Public Economics 1: 323-338.

Alm, J. 2014. Does an uncertain tax system encourage "aggressive tax planning"? Economic Analysis and Policy 44: 30-38.

Alm, J., T. Cherry, M. Jones, and M. McKee. 2010. Taxpayer information assistance services and tax compliance behavior. Journal of Economic Psychology 31: 577-586.

Alm, J., and B. Torgler. 2011. Do ethics matter? Tax compliance and morality. Journal of Business Ethics 101 (4): 635-651.

Bundesministerium für Finanzen. 2012. Geschäftsbericht 2011 der österreichischen Steuer- und Zollverwaltung. Retrieved from BMF website:https://www.bmf.gv.at/services/publikationen/BMFGeschaeftsbericht_2011_der_oesterreichischen_Steuer-_und.pdf.

de Rosa, A.S. 1995. Le „réseau d'associations"comme methode d'etude dans la recherche sur les représentations sociales: Structure, contenus et polarité du champ semantique. Cahiers Internationaux de Psychologie Sociale 15: 145-157. 
de Widt, D., and L. Oats. 2017. Risk assessment in a co-operative compliance context: A Dutch-UK comparison. British Tax Review 2017 (2): 230-248.

Ehrke-Rabel, T., and B. Gunacker-Slawitsch. 2014. Die Bedeutung von Governance für das Steuerrecht. Austrian Law Journal 2014 (1): 99-111.

Eichfelder, S., and C. Kegels. 2014. Compliance costs caused by agency action? Empirical evidence and implications for tax compliance. Journal of Economic Psychology 40 (1): 200-219.

Erwin, D.G., and A.N. Garman. 2010. Resistance to organizational change: Linking research and practice. Leadership \& Organization Development Journal 31 (1): 39-56.

Feld, L.P., and B. Frey. 2007. Tax compliance as the result of a psychological tax contract: The role of incentives and responsive regulation. Law and Policy 29 (1): 102-120.

Greenacre, M.J. 1991. Interpreting multiple correspondence analysis. Applied Stochastic Models and Data Analysis 7 (2): 195-210.

Greenarcre, M. 2007. Correspondence analysis in practice, 2nd ed. London: Chapman \& Hall/CRC.

Iverson, R.D. 1996. Employee acceptance of organizational change: the role of organizational commitment. International Journal of Human Resource Management 7 (1): 122-149.

Kirchler, E. 2007. The economic psychology of tax behavior. Cambridge: Cambridge University Press.

McGuire, S.T., T.C. Omer, and J.H. Wilde. 2014. Investment opportunity sets, operating uncertainty, and capital market pressure: Determinants in investments of tax shelter activities. Journal of the American Taxation Association 36 (1): 1-26.

Moscovici, S. 1963. Attitudes and opinions. Annual Review of Psychology 14 (1): 231-260.

Müller, E. 2014. Steuern und Governance. Austrian Law Journal 2014 (1): 112-119.

OECD. 2008. Study into the role of tax intermediaries. Retrieved from OECD website: http://www.oecd. org/tax/administration/39882938.pdf.

OECD. 2013. Co-operative compliance: A framework. Retrieved from OECD website: http://www.oecd. org/ctp/administration/Co-operative-Compliance-Preliminary.pdf.

Olsen, J., M. Kang, and E. Kirchler. 2018. Tax psychology. In The Cambridge handbook of psychology and economic behaviour, 2nd ed, ed. A. Lewis, 405-429. Cambridge: Cambridge University Press.

Oreg, S. 2006. Personality, context, and resistance to organizational change. European Journal of Work and Organizational Psychology 15 (1): 73-101.

Palmer, I., R. Dunford, and D. Buchanan. 2016. Managing organizational change: A multiple perspectives approach, 3rd ed. New York: McGraw-Hill Education.

Piderit, S.K. 2000. Rethinking resistance and recognizing ambivalence: A multidimensional view of attitudes toward an organizational change. The Academy of Management Review 25 (4): 783-794.

Schrittwieser, E., and H. Woischitzschläger. 2014. Horizontal Monitoring in Österreich. CFO aktuell 8 (2): 62-63.

Stark, J., T. el Sehity, and E. Kirchler. 2017. Soziale Repräsentationen - soziale Vorstellungen. In Kommunikation, Interaktion und soziale Gruppenprozesse (Enzyklopädie der Psychologie, Sozialpsychologie, ed. H.-W. Bierhoff and D. Frey, 63-81. Göttingen: Hogrefe.

Stevens, L. G. M., Pheijffer, M., van den Broek, J. G. A., Keijzer, T. J., \& van der Hel-van Dijk, E. C. J. M. 2012. Tax supervision-made to measure. Retrieved from Belastingdienst website: https:// download.belastingdienst.nl/belastingdienst/docs/tax_supervision_made_to_measure_ tz0151z1fdeng.pdf.

Stiastny, M. 2015. Horizontal monitoring. Implikationen für das österreichische Steuerrecht. Vienna: LexisNexis.

Tyler, T.R. 1997. The psychology of legitimacy: a relational perspective on voluntary deference to authorities. Personality and Social Psychology Review 1 (4): 323-345.

van Der Hel-van Dijk, L., and T. Poolen. 2013. Horizontal monitoring in the Netherlands: at the crossroads. Bulletin for International Taxation 67 (12): 673-678.

Whitlark, D.B., and S.M. Smith. 2001. Using correspondence analysis to map relationships. Marketing Research 13 (3): 22-27. 